\title{
Laxative Effect of Eugenia jambolana Crude Leaf Bud Extract
}

\author{
A. Sivakumar ${ }^{1 *}$ T. Panneer Selvam ${ }^{2}$ \\ ${ }^{1}$ School of Bio Science and Technology, VIT University, Tamilnadu, India; ${ }^{2}$ Department of Pharmacy, Srinivas College of Pharmacy, \\ Karnataka, India. \\ Email: *tpsphc@gmail.com, siva_kumar.a@vit.ac.in
}

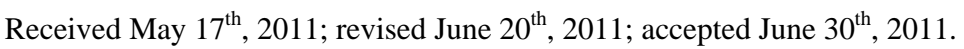

\begin{abstract}
The therapeutic value of Eugenia jambolana Lam. commonly known as 'Jamun' has been recognized in different system of traditional medication for the treatment of different diseases and ailments. It contains several phytoconstituents belonging to category of alkaloids, glucosides, flavonoides and volatile oils. It has been reported as digestive, astringent to the bowels, anthelmintic, sore throat, bronchitis, asthma, thirst, biliousness, dysentery, blood purifier, ulcers and diabetes. There are few reports available on clinical uses of Eugenia jambolana in diabetes that have shown promising results. In south India ayurvedic practitioners were using the leaf buds of Eugenia jambolana to induce laxative effect and to clean up the intestinal contents before starting any medication. The result showed that of E. jambolana stimulates the contractile action of frog and mice through an acetylcholine-like mechanism and effectively stimulates gastrointestinal motility in mice and frogs. In this paper we have discussed the laxative effect of Eugenia jambolana leaf bud extract which was never reported scientifically.
\end{abstract}

Keywords: Eugenia jambolana, Traditional Medicine, Laxative

\section{Introduction}

Traditional or indigenous drugs used by different ethnic groups of the world for the treatment of diseases have special significance of having been tested on long time scale. They are relatively safe, easily available and affordable to masses. Eugenia jambolana Lam belonging to the family Myrtaceae is a large evergreen tree up to 30 $\mathrm{m}$ high. It is widely distributed through out India, and known as Jamun. It has been valued in Ayurveda and Unani system of medication for possessing variety of therapeutic properties. Most of the plant parts of E. jambolana are used in traditional system of medicine in India. According to Ayurveda, its bark is acrid, sweet, digestive, and astringent to the bowels, anthelmintic and in good for sore throat, bronchitis, asthma, thirst, biliousness, dysentery, blood impurities and to cure ulcers [1-8]. The fruits are acrid and sweet, cooling, dry and astringent to bowels. The seeds are sweet, astringent to bowels and good for diabetes. The sprouts are refrigerant, carminatives \& astringent to bowels. Its bark, with or without the addition of other astringents like cardamom and cinnamon, is used as decoction in case of chronic diarrhoea and dysentery. Juice of the tender leaves of $E$. jambolana together with mango leaves and myrobalan is administered along with goat's milk and honey to cure dysentery with bloody discharge (Chakardata) where as juice of tender leaves alone or in combination with carminatives is given along with goat's milk to cure diarrhoea in children. Timbola et al., isolated quercetin (0.0085\%), myricetin $(0.023 \%)$, myricitrin $(0.009 \%)$, and a flavonol glycosides myricetin 3-O-(4"-acetyl)- $\alpha$-Lrhamnopyranosides $(0.059 \%)$ from its leaves. Traditional Ayurvedic practioners in tamil nadu used the E. jambolana leaf bud as purgative/laxative to clean up gastro intestinal tract before starting any other medication or treatment. Literature survey revealed that the plant extract has yet not been screened for its traditional laxative and purgative effects in experimental animals. Therefore the present study was carried out to provide pharmacological evidence for the folkore medicinal consideration of leaf bud crude extract as laxative.

\section{Results}

\subsection{Effect of $E$. jambolana on Gastrointestinal Motility and Laxative Effect}

The effect of $E$. jambolana on the gastrointestinal motil- 
Table.1 Effect of E. jambolana on gastrointestinal motility and laxative effect in frogs.

\begin{tabular}{|c|c|c|c|c|}
\hline S. No & Drug & Oral dose & Charcoal dose & $\begin{array}{c}\text { \% Length of } \\
\text { charcoal moved }\end{array}$ \\
\hline 1. & Saline & $1 \mathrm{~mL}$ & $1 \mathrm{ml}$ & 15 \\
\hline 2. & Dulcolax & $1 \mathrm{~mL}$ & $1 \mathrm{ml}$ & 83 \\
\hline 3. & $\begin{array}{c}\text { E. jambolana crude } \\
\text { leaf bud extract }\end{array}$ & $1 \mathrm{mg} / \mathrm{mL}$ & $1 \mathrm{ml}$ & 78 \\
\hline 4. & $\begin{array}{c}\text { E. jambolana crude } \\
\text { leaf bud extract }\end{array}$ & $2 \mathrm{mg} / \mathrm{mL}$ & $1 \mathrm{ml}$ & 82 \\
\hline 5. & $\begin{array}{l}\text { E. jambolana crude } \\
\text { leaf bud extract }\end{array}$ & $3 \mathrm{mg} / \mathrm{mL}$ & $1 \mathrm{ml}$ & 89 \\
\hline
\end{tabular}

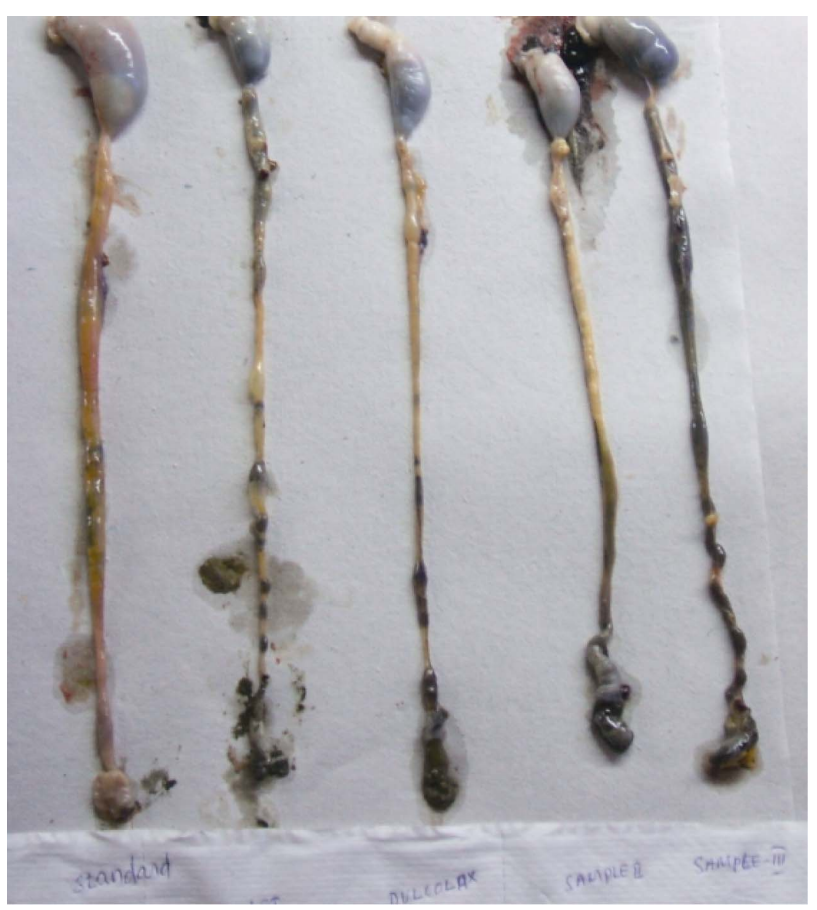

Figure 1. Distance traveled by the charcoal in frog's gut.

ity tested on frogs as per the protocol motioned in materials and methods. The distance traveled by the charcoal plug from the pylorus to the caecum was measured, and expressed as the percent of the total length of the distance (Figure 1). The motility and laxative effect value presented in Table $\mathbf{1 .}$

\subsection{Laxative Activity of $\boldsymbol{E}$. jambolana in Albino Mice}

In albino mice the appearance of pasty stools was noted in the E. jambolana crude leaf bud extract treated and control mice. The statistical significance of the difference between the data of two groups was calculated and values are presented in Table 2.

\subsection{Spasmogenic Effect in Isolated Frog Ileum}

We performed a pharmacological evaluation of a herbal laxative of E. jambolana, which induced a large spas-

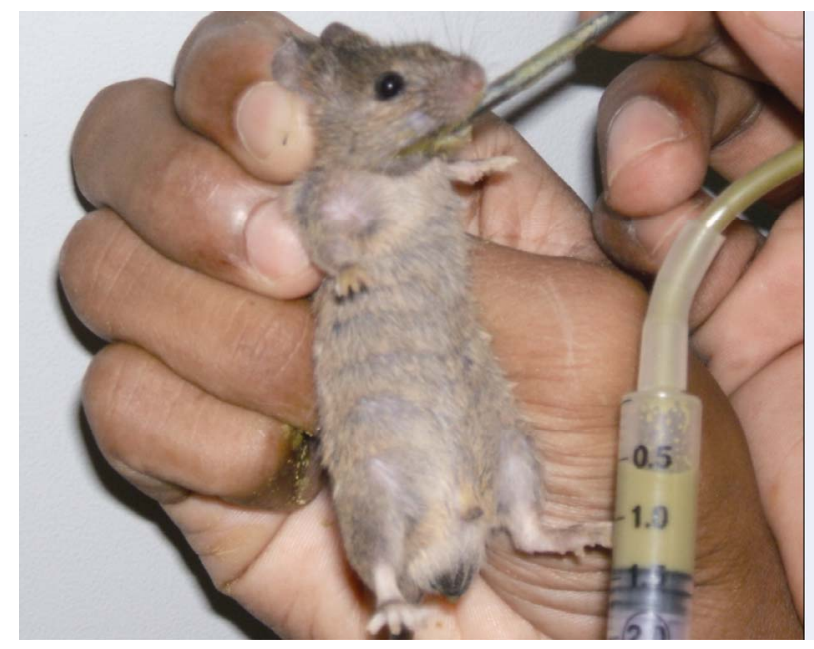

Table 2. Purgative activity of $\boldsymbol{E}$. jambolana crude leaf bud extract in albino mice.

\begin{tabular}{cccc}
\hline S. No & Drug & Oral dose & Appearance of pasty stool \\
1. & Saline & $5 \mathrm{~mL}$ & $112 \mathrm{~min} \pm 6 \mathrm{~min}$ \\
2. & Caster oil & $2 \mathrm{~mL}$ & $37 \pm 10 \mathrm{~min}$ \\
3. & $\begin{array}{c}\text { E. jambolana } \text { crude } \\
\text { leaf bud extract }\end{array}$ & $1 \mathrm{gm} / \mathrm{mL}$ & $60 \pm 7 \mathrm{~min}$ \\
4. & $\begin{array}{c}\text { E. jambolana } \mathrm{crude} \\
\text { leaf bud extract }\end{array}$ & $2 \mathrm{gm} / \mathrm{mL}$ & $59 \pm 7 \mathrm{~min}$ \\
5. & $\begin{array}{c}\text { E. jambolana } \mathrm{crude} \\
\text { leaf bud extract }\end{array}$ & $3 \mathrm{gm} / \mathrm{mL}$ & $55 \pm 8 \mathrm{~min}$ \\
\hline
\end{tabular}

( $\mathrm{n}=6$ in each group).

mogenic effect that was more or less equal to acetylcholine in isolated frog ileum. Atropine inhibited the spasmogenic effect of of E. jambolana and Ach, suggesting that E. jambolana acts via a cholinergic mechanism

\section{Discussion}

The result shows that the distance travelled by the charcoal in E. jambolana treated frog's gut is dose dependent. Dulcolax and E. jambolana were having more or less equal laxative effect among the frog groups. In case of the albino mice the castor oil was very effective with respect to time taken to exert laxative effect. E. jambolana took only half of the time when compared with normal saline for the Appearance of pasty stool. This shows that E. jambolana was excerting very good laxative effect in albino mice. The contractile effect of of $E$. jambolana appears to be mediated through an acetylcholine-like mechanism. A neurotransmitter released by the parasympathetic nervous system, acetylcholine acts in the gut by stimulating M3 muscarinic receptor subtypes; atropine blocks all muscarinic receptor sites. Through this mechanism, acetylcholine plays an important physiological role in regulating the peristaltic movements of the gut. We observed that of E. jambolana exerted an effect similar to that of acetylcholine. In conclusion, our 
data show that of E. jambolana stimulates the contractile action of frog and mice through an acetylcholine-like mechanism. We showed that of E. jambolana effectively stimulates gastrointestinal motility in mice and frogs. These data suggest that of E. jambolana is a valid, safe folk laxative.

\section{Experimental}

\subsection{Materials and methods}

E. jambolana leaf buds were collected from the local farms of vellore districts tamil nadu in the month of November-December-2009. The fresh leaf buds were weighed and ground using mortal and pistol, the crude extract adjusted to the final concentration of $100 \mathrm{mg} / \mathrm{mL}$ using sterial distilled water. This crude extract was used to test laxative effect in frogs, rats, as animal models. Acetylcholine per chlorate, atropine sulfate and gum tragacanth were purchased from Sigma Chemicals. Castor oil was purchased from local market. Commercially available dulcolax (bisacodyl) tablets used as standard drug for laxative effect.

\subsection{Identify the Headings}

We selected laxatives commonly used in India to compare with E. jambolana. The laxative Dulcolax was obtained from pharmaceutical shops. Dulcolax tablets were dissolved in sterial distilled water.

Frogs (150 g - 200 g) were purchased from local supplier. Mice were obtained from the Animal Breeding Laboratory. All animals were housed at the Animal biotechnology Laboratory of the University, and kept at $23^{\circ} \mathrm{C}-25^{\circ} \mathrm{C}$. Animals had free access to water and food. Frogs were sacrificed by standard methods. All the efforts were made to minimize animal suffering by guidelines of ani- mal laboratory of the University

\subsection{Effect of $E$. jambolana on Gastrointestinal Motility and Laxative Effect}

The effect of $E$. jambolana on the gastrointestinal motility was tested on frogs (four frogs per group). The animals were starved for $24 \mathrm{~h}$ prior to the experiment. The frogs were given orally with the E. jambolana, or dulcolax, or distilled water. The Laxative activities of E. jambolana were conducted on frogs by giving $1 \mathrm{mg} / \mathrm{ml}, 2$ $\mathrm{mg} / \mathrm{ml}, 3 \mathrm{mg} / \mathrm{ml}$ of $E$. jambolana leaf bud crude extracts through oral route. The standard or control groups were given with $1 \mathrm{~mL}$ of sterile distilled water. Positive control or dulcolax group were given with $10 \mathrm{mg} / \mathrm{kg}$ of body weight. At 5 min after drug administration, $1 \mathrm{~mL}$ of a $5 \%$ charcoal suspension in $10 \%$ aqueous solution of tragacanth powder was administered orally to each animal. The animals were killed 15 min later when the charcoal reached to $50 \%$ of distance from the pylorus to the caecum in control, to open the abdomens. The distance traveled by the charcoal plug from the pylorus to the caecum was measured, and expressed as the percent of the total length of the distance. The motility and laxative effect value presented in Table 1.

\subsection{Laxative Activity of E. jambolana in Albino Mice}

Albino mice fasted for $24 \mathrm{~h}$ were divided in groups of six animals each and were fed with different doses of the $E$. jambolana crude leaf bud extract or castor oil 0.2 $\mathrm{mL} / 20 \mathrm{~g}$ in the form of emulsion. They were then fed corn meal diet and time for the appearance of pasty stools was noted in the treated and control mice. The statistical significance of the difference between the data of two groups was calculated and values are presented in Table 2.

\subsection{Spasmogenic Activity of $E$. jambolana in Isolated Tissue Preparations}

The spasmogenic activities of E. jambolana were conducted using isolated frog ileum preparations. Segments of ileum $2 \mathrm{~cm}$ long were suspended in a $100 \mathrm{ml}$ tissue bath containing Tyrode's solution, bubbled with a mixture of $95 \% \mathrm{O}_{2}$ and $5 \% \mathrm{CO}_{2}$, and maintained at $37^{\circ} \mathrm{C}$. Intestinal responses were recorded isotonically using Bio-Science transducers and an oscillograph. Each tissue was allowed to equilibrate for at least $10 \mathrm{~min}$ before the addition of E. jambolana $(1 \mathrm{~g} / \mathrm{ml})$ or any drugs. The contractile effect of the test materials was assessed as a percentage of the maximum effects that were induced by acetylcholine $(0.2 \mathrm{M}, 0.06 \mathrm{~g} / \mathrm{ml})$. To see whether the contractile effect of $E$. jambolana

was mediated through acetylcholine-like mechanism, the tissue was pre-treated with atropine $(0.1 \mathrm{M})$ and allowed to equilibrate for $15 \mathrm{~min}$ before the re-determination of the effect of $E$. jambolana or acetylcholine.

\section{References}

[1] P. A. Akah, C. N. Aguwa and R. U. Agu, "Studies on the Antidiarrhoeal Properties of Pentaclethra Macrophylla Leaf Extracts,” Phytotherapy Research, Vol. 13, No. 4, 1999, pp. 292-295. doi:10.1002/(SICI)1099-1573(199906)13:4<292::AID-P TR415>3.0.CO;2-N

[2] D. F. Altman, "Drugs Used in Gastrointestinal Diseases," In: B. G. Katzung, Ed., Basic and Clinical Pharmacology, 8th Edition, Lange Medical Books/MaGraw Hill, New York, 2001, pp. 1070-1071.

[3] J. H. Brown and P. Taylor, "Muscarinic Receptor Agonists and Antagonists,” In: J. G. Hardman, L. E. Limbird, P. B. Molinoff, et al., Eds, The Pharmacological Basis of Therapeutics, 9th Edition, McGraw Hill, New York, 1996, 
pp. 141-159.

[4] H. J. Chi and H. S. Kim, "Studies on the Components of Umbelliferae Plants in Korea: Pharmacological Study of Decursin, Decursinol and Nodakenin,” Korean Journal of Pharmacognosy, Vol. 1, 1970, pp. 25-32.

[5] L. C. Chiang, W. Chiang, M. Y. Chang and C. C Lin, “In Vitro Cytotoxic, Antiviral and Immunomodulatory Effects of Plantago Major and Plantago Asiatica," American Journal Chinese Medicine, Vol. 31, No. 2, 2003, pp. 225-234. doi:10.1142/S0192415X03000874

[6] J. E. Everhart, V. L. Go, R. S. Johannes, S. C. Fitzsim- mons, H. P. Roth and L. R. White, "A Longitudinal Survey of Self-Reported Bowel Habits in the United States," Digestive Diseases and Sciences, Vol. 34, No. 8, 1989, pp. 1153-1162. doi:10.1007/BF01537261

[7] W. G. Le, "Anti-diarrheal and Spasmolytic Activities and Acute Toxicity Study of Soonkijangquebo, a Herbal AntiDiarrheal Formula,” Journal of Ethno pharmacol, Vol. 91, No. 1, 2004, pp. 75-80. doi:10.1016/j.jep.2003.11.019

[8] L. R. Schiller, “The Therapy of Constipation," Aliment Pharmacol Therapeutics, Vol. 15, No. 6, 2001, pp. 749-763. doi:10.1046/j.1365-2036.2001.00982.x 